\title{
Impact of different housing modification systems on growth performance and feed intake of Gir calves during winter season
}

\author{
Maya Jat ${ }^{1}$, Ram Prasad Jat ${ }^{1}$, Vinod Bhateshwar ${ }^{2}$, Vinod Kumar Paswan ${ }^{2}$ and Hanuman Lal Nehra ${ }^{1}$
}

Received: 22 July 2021 / Accepted: 20 August 2021 / Published online: 31 October 2021

(C) Indian Dairy Association (India) 2021

\begin{abstract}
The current study was carried out to investigate the impact of different housing modification systems on growth performance and feed intake of Gir calves during winter season. Selected 24 Gir calves of 12 months old were randomly divided into three homogenous modified housing groups containing with eight calves in each viz., group GC-1: conventional barn (during night) + open paddock (during day), GC-2: conventional barn + rubber mat and GC-3: loose house + curtains (during night). The concentrate supplement was given $1.5 \mathrm{~kg} / \mathrm{calve} /$ day as pellet feed, green lucerne (Medicago sativa) $2.5 \mathrm{~kg} / \mathrm{calve} /$ day and wheat straw (Triticum aestivum) ad lib as dry fodder. During the statistical analysis, the mean of morning minimum temperature $(\mathrm{P}<0.05)$ was higher in $\mathrm{GC}-2\left(11.81^{\circ} \mathrm{C}\right)$ over than $\mathrm{GC}-3\left(11.27^{\circ} \mathrm{C}\right)$ and $\mathrm{GC}-1\left(10.64^{\circ} \mathrm{C}\right)$ and the morning maximum temperature was significantly higher in $\mathrm{GC}-3\left(22.97^{\circ} \mathrm{C}\right)$, which was above than groups $\mathrm{GC}-2\left(22.39^{\circ} \mathrm{C}\right)$ and $\mathrm{GC}-1\left(22.21^{\circ} \mathrm{C}\right)$. However, the mean value of the evening minimum temperature was significantly lower in GC-1 $\left(11.67^{\circ} \mathrm{C}\right)$ followed by GC-3 $\left(11.86^{\circ} \mathrm{C}\right)$ and GC-2 $\left(12.40^{\circ} \mathrm{C}\right)$ and the evening maximum temperature was highest in $\mathrm{GC}-1$
\end{abstract}

${ }^{1}$ Department of Livestock Production Management, Sri Karan Narendra Agriculture University, Jobner- 303 329, Rajasthan, India

${ }^{2}$ Department of Dairy Science and Food Technology, Institute of Agricultural Sciences, Banaras Hindu University, Varanasi- 221 005, Uttar Pradesh, India

Vinod Bhateshwar $(\bowtie)$

Department of Dairy Science and Food Technology, Institute of Agricultural Sciences, Banaras Hindu University, Varanasi-221 005, Uttar Pradesh, India

E-mail: vinod.bhateshwar@bhu.ac.in $\left(24.95^{\circ} \mathrm{C}\right)$ followed by GC-3 $\left(23.98^{\circ} \mathrm{C}\right)$ and $\mathrm{GC}-2\left(23.54^{\circ} \mathrm{C}\right)$. The average mean of both relative humidity $(\mathrm{RH})$ percent and temperature humidity index (THI) along with morning and evening times was $(\mathrm{P}<0.05)$ higher in $\mathrm{GC}-2$ than $\mathrm{GC}-1$ and $\mathrm{GC}-3$ groups. However, total dry matter intake, voluntary water intake and feed conversion efficiency were significantly higher in the GC-1 group compared to the calves in the GC-2 and GC-3 groups. The initial body weight of the claves was similar as 122.37, 121.13 and 121.88 $\mathrm{kg}$ in GC-1, GC-2 and GC-3 groups. However, the final body weight of the calves was significantly $(\mathrm{P}<0.05)$ highest in group GC-1 $(170.12 \mathrm{~kg})$ followed by GC-2 (163.61 kg) and GC-3 (162.36 kg) respectively. The average daily weight gain was significantly achieved by GC-1 (530.90 g/day) followed by GC-2 (472.05 g/ day) and GC-3 (449.88 g/day). It was concluded that the housing modification system can be effectively used to improve the growth performance, feed intake and sheds micro-climate of Gir calves during the winter season.

Keywords: Body weight; Feed efficiency; Feed intake; Gir calves; Housing modification; Micro-climate

Housing is one of the foremost requirements of dairy animals for better production, health and welfare. Housing protects animals from adverse climatic conditions, provides comfort for resting, eating, drinking, walking and prevents injury and disease (Anderson, 2002). The calves growth may be adversely affected by the environmental stress during management practices (Laxmi et al. 2013). Dairy cow shelters will be designed to modify the micro environment and protect the animals from severe weather conditions to reduce peak stress levels (Sinha et al. 2018). Kumat et al. (2016) reported that loose housing modified shed were improved productivity during the autumn and winter seasons. Therefore, the present investigation was conducted to assess the impact of different housing modification systems on growth performance and feed intake of Gir calves during winter season.

The current study was carried out on the dairy farm of Sri Karan Narendra Agriculture University, Jobner (Rajasthan) from November 2019 to March 2020, with the total duration of the experiment being 105 days, i.e. first preliminary (adaptation) period 
for 15 days and the next 90 days of actual trail period. Twentyfour healthy Gir calves of both sex with approximately the same body weight $(121.79 \pm 18.76 \mathrm{~kg})$ and 12 months old were selected. The calves were randomly divided into three identical modified housing groups with eight calves in each group viz., group GC1: conventional barn (during night) + open paddock (during day), GC-2: conventional barn + rubber mat and GC-3: loose house + curtains (during night). The following changed housing conditions were used for all groups during the experimental period: GC-1 group of calves were tied at the neck with iron-chains, fed individually and allow open paddocks during the day (08: $00 \mathrm{am}$ to $05: 00 \mathrm{pm})$ and closed at night in winter (05: $00 \mathrm{pm}$ to $08: 00 \mathrm{am})$. GC-2 group the conventional barn is completely closed structure as roofed and walls are also complete with windows and ventilators to get proper ventilation and lighting. The calves were tied to their neck with iron-chains and the rubber mat was laid on the floor in this barn to protect them from the cold. The calves in the GC-3 group were kept in the loose house for around 24 hours. The loose house had a covered area with simple asbestos sheet roofs and an open area paved with kaccha brick, which surrounded on three sides by 1.5 meters high walls, but gunny bag curtains were fitted in the open front side, only made available to the claves at night. Twice a day (10:30 am and 4:00 $\mathrm{pm}$ ) the experimental calves received a basic diet with dry fodder as wheat straw (Triticum aestivum) ad lib and green lucerne (Medicago sativa) $2.5 \mathrm{~kg} /$ calve/days as green fodder and $1.5 \mathrm{~kg}$ concentrate as pellet feed with free access to water. The concentrate mixture contained $19.26 \%$ crude protein, $3.60 \%$ ether extract and $6.22 \%$ crude fiber.

Meteorological observations such as maximum, minimum, dry and wet bulb temperatures of different modified sheds were recorded daily at 07:30 am and 02:30 pm during the experiment. The relative humidity $(\mathrm{RH})$ was calculated using the hygrometric tables (Indian Meteorological Department, Pune) from the readings of the dry and wet thermometer. The Temperature
Humidity Index (THI) was calculated according to the formula of McDowell (1972).

$\mathrm{THI}=0.72\left(\right.$ dry bulb temperature ${ }^{\circ} \mathrm{C}+$ wet bulb temperature $\left.{ }^{\circ} \mathrm{C}\right)+$ 40.6

The amount of green fodder (lucerne), dry fodder (wheat straw) and concentrate (pellet feed) were offered to the animals and the leftover was weighed on two consecutive days at weekly intervals during the experiment for analysis of dry matter intake (DMI). The samples of feed and fodder were analyzed for proximate principles (AOAC, 2000). The calves voluntary water intake was recorded once a week, morning and evening by offering a measured quantity of clean and fresh water through a measured/ marked bucket during the experiment. All calves were weighted at the beginning and monthly intervals as well as at the end of the experiment. The body weights of the calves were recorded in the morning at 08:00 am before providing water and feed. Fasting before weighing was done in an attempt to reduce the gut fill and thereby minimizing the weight fluctuations.

In the present study, the mean of the morning minimum temperature was significantly $(\mathrm{P}<0.05)$ higher in $\mathrm{GC}-2\left(11.81^{\circ} \mathrm{C}\right)$ over than $\mathrm{GC}-3\left(11.27^{\circ} \mathrm{C}\right)$ and $\mathrm{GC}-1\left(10.64^{\circ} \mathrm{C}\right)$ groups. The morning minimum temperature was higher in the conventional barn (GC2 ) as compared to the loose house (GC-3) due to the protection against the cold through the maximum area enclosed by a wall. The average morning maximum temperature was significantly higher $(\mathrm{P}<0.05)$ in $\mathrm{GC}-3\left(22.97^{\circ} \mathrm{C}\right)$ than in $\mathrm{GC}-2\left(22.39^{\circ} \mathrm{C}\right)$ and $\mathrm{GC}-$ $1\left(22.21^{\circ} \mathrm{C}\right)$. However, the mean value of evening minimum temperature was recorded significantly lower in $\mathrm{GC}-1\left(11.67^{\circ} \mathrm{C}\right)$ followed by $\mathrm{GC}-3\left(11.86^{\circ} \mathrm{C}\right)$ and $\mathrm{GC}-2\left(12.40^{\circ} \mathrm{C}\right)$. While the average means value of the evening maximum temperature was noted significantly in $\mathrm{GC}-1\left(24.95^{\circ} \mathrm{C}\right)$ then followed by $\mathrm{GC}-3\left(23.98^{\circ} \mathrm{C}\right)$ and $\mathrm{GC}-2\left(23.54^{\circ} \mathrm{C}\right)$. The average mean Relative Humidity $(\mathrm{RH})$ percent in both morning and evening times was significantly

Table 1 Average dry matter intake (DMI) and voluntary water intake (VWI) in Gir calves

\begin{tabular}{llll}
\hline Parameters & GC-1 & GC-2 & GC-3 \\
\hline DMI, kg/day & $2.32^{\mathrm{a}} \pm 0.01$ & $2.04^{\mathrm{b}} \pm 0.01$ & $1.92^{\mathrm{c}} \pm 0.03$ \\
Wheat straw & $0.61^{\mathrm{a}} \pm 0.00$ & $0.61^{\mathrm{a}} \pm 0.00$ & $0.61^{\mathrm{a}} \pm 0.00$ \\
Green lucerne & $1.35^{\mathrm{a}} \pm 0.00$ & $1.35^{\mathrm{a}} \pm 0.00$ & $1.35^{\mathrm{a}} \pm 0.00$ \\
Concentrate mixture & $4.28^{\mathrm{a}} \pm 0.01$ & $4.00^{\mathrm{b}} \pm 0.01$ & $3.88^{\mathrm{c}} \pm 0.01$ \\
Total DMI & $2.93^{\mathrm{a}} \pm 0.08$ & $2.80^{\mathrm{b}} \pm 0.09$ & $2.77^{\mathrm{bc}} \pm 0.13$ \\
DMI kg/100 kg BW & & & $3.65^{\mathrm{c}} \pm 0.03$ \\
VWI, lit & $4.64^{\mathrm{a}} \pm 0.04$ & $4.51^{\mathrm{ab}} \pm 0.03$ & $6.68^{\mathrm{b}} \pm 0.04$ \\
Morning & $7.55^{\mathrm{a}} \pm 0.04$ & $6.65^{\mathrm{b}} \pm 0.04$ & $10.33^{\mathrm{c}} \pm 0.04$ \\
Evening & $12.19^{\mathrm{a}} \pm 0.05$ & $11.16^{\mathrm{b}} \pm 0.05$ & $2.71^{\mathrm{c}} \pm 0.03$ \\
VWI/day & $2.85^{\mathrm{a}} \pm 0.02$ & $2.81^{\mathrm{ab}} \pm 0.02$ & \\
VWI/kg DMI &
\end{tabular}

$\mathrm{a}, \mathrm{b}$ and $\mathrm{c}$ means with different superscripts are significantly different $(\mathrm{P}<0.05)$ in a row 
Table 2 Feed conversion efficiency in Gir calves (twelve months to fifteen months)

\begin{tabular}{llll}
\hline Attributes & GC-1 & GC-2 & GC-3 \\
\hline Initial weight $(\mathrm{kg})$ at 365 days & $122.37^{\mathrm{a}} \pm 4.92$ & $121.13^{\mathrm{b}} \pm 6.32$ & $121.88^{\mathrm{bc}} \pm 8.96$ \\
Final weight $(\mathrm{kg})$ at 455 days & $170.12^{\mathrm{a}} \pm 14.16$ & $163.61^{\mathrm{b}} \pm 12.65$ & $162.36^{\mathrm{c}} \pm 10.98$ \\
Total gain $(\mathrm{kg})$ in 90 days & $47.78^{\mathrm{a}} \pm 0.53$ & $42.48^{\mathrm{b}} \pm 0.54$ & $40.48^{\mathrm{c}} \pm 0.76$ \\
Average daily gain (g/day) & $530.90^{\mathrm{a}} \pm 24.21$ & $472.05^{\mathrm{b}} \pm 38.84$ & $449.88^{\mathrm{c}} \pm 26.49$ \\
Total feed intake (wheat straw + green lucerne + concentrate) & $385.20^{\mathrm{a}}$ & $360.00^{\mathrm{b}}$ & $349.20^{\mathrm{c}}$ \\
(kg) in 90 days & & & \\
Feed efficiency $(\%)$ & $12.40^{\mathrm{a}}$ & $11.80^{\mathrm{b}}$ & $11.59^{\mathrm{c}}$ \\
\hline
\end{tabular}

$\mathrm{a}, \mathrm{b}$ and $\mathrm{c}$ means with different superscripts are significantly different $(\mathrm{P}<0.05)$ in a row

$(\mathrm{P}<0.05)$ higher in GC-2 (80.92\% and $62.10 \%)$ over than in $\mathrm{GC}-1$ (77.44\% and 59.20\%) and GC-3 (75.78\% and 57.60\%). The wide gap in the morning relative humidity may be due to frequent water supplies and morning washing of the animal shed. The values of the Temperature Humidity Index (THI) were recorded both in the morning and evening times significantly $(\mathrm{P}<0.05)$ higher in GC-2 (61.35 and 70.00) than in the GC-1(60.15 and 66.68) and GC-3 (59.11 and 65.47) groups respectively. Similar trends were observed in calves and heifers through various houses modifications in winter concerning temperature, $\mathrm{RH}$ and THI by (Jat et al. 2003; Jat and Yadav, 2010; Kailash et al. 2018). While, Shekhawat and Choudhary (2012) reported different trends during the winter season in their study of lactating crossbred cows, which could be due to variations in the place or the location system of housing.

The average daily total dry matter intake (TDMI) of calves in different groups is presented in (Table 1). However, the TDMI (kg/day) and DMI ( $\mathrm{kg} / 100 \mathrm{~kg} \mathrm{BW})$ during the experiment were significantly $(\mathrm{P}<0.05)$ higher in GC-1 $(4.28 \pm 0.01 \mathrm{~kg}$ and $2.93 \pm 0.08$ $\mathrm{kg}$ ) compared to calves of the GC-2 and GC-3 groups. The higher DMI in both groups GC-1 and GC-2 than in the GC-3 group may be due to protection from cold winds that resulted in better growth by diverting the nutrients for growth. Similar results were obtained in the different studies by (Jat et al. 2003; Kailash et al. 2017). However, in another study according to (Lowe et al. 2019) floor type, as a completely slatted concrete floor or a completely slatted concrete floor covered with rubber strips, had no significant effect on forage or total dry matter intake over the entire trial period.

The results (Table 1) showed that the average daily voluntary water intake (lit/day) and voluntary water intake $(\mathrm{kg} / \mathrm{DMI})$ were significantly $(\mathrm{P}<0.05)$ higher in both groups GC-1(12.19 \pm 0.05 lit. and $2.85 \pm 0.02$ lit.) and GC-2 (11.16 \pm 0.05 lit. and $2.81 \pm 0.02$ lit.) than in group GC-3 ( $10.33 \pm 0.04$ lit. and $2.71 \pm 0.03$ lit.). The VWI is mostly connected to the DMI of the animals, there was a positive correlation between the water intake and the DMI of Gir calves. Similar results were obtained by Jat et al. (2003) and Kailash et al. (2017).

The results of table 2 revealed that the initial (365 days of age) body weight of Gir calves were similar as $122.37 \pm 4.92,121.13 \pm 6.32$ and $121.88 \pm 8.96 \mathrm{~kg}$ in group GC-1, GC-2 and GC-3 respectively and the corresponding final body weight at 455 days of age in groups GC-1, GC-2 and GC-3 has significantly differed $170.12 \pm 14.6$, $163.61 \pm 12.65$ and $162.36 \pm 10.98 \mathrm{~kg}$. The findings of the present result are in agreement with Kailash et al. (2018) who reported that the body weight of claves significantly improved conventional barn with an open shed during the winter season under semi-arid environmental conditions.

The average daily weight gain (ADG) as depicted in table 2 indicates that the significantly $(\mathrm{P}<0.05)$ higher rate in $\mathrm{GC}-1$ $(530.50 \pm 24.21 \mathrm{~g} / \mathrm{day})$, which was over than GC-2 $(472.05 \pm 38.84 \mathrm{~g} /$ day) and GC-3 (449.88 $\pm 26.49 \mathrm{~g}$ /day) groups. Similarly, Jat and Yadav (2010) and Kailash et al. (2017) observed that protecting buffaloes and cross-bred cows calves from cold stress during the winter season improved calves growth performance.

The total feed intake during 90 days found out highest in Gir calves of GC-1 $(385.20 \mathrm{~kg})$ followed by GC-2 $(360.00 \mathrm{~kg})$ and lowest in GC-3 $(349.20 \mathrm{~kg}$ ) respectively (Table 2$)$. However, the highest feed conversion efficiency percent was recorded in GC-1 $(12.40 \%)$ over than GC-2 (11.80\%) and GC-3 (11.59\%) groups. This feed conversion efficiency percent was better in GC-1 due to the higher growth rate as well as the physical comfort and higher feed intake of these calves the during winter season. The findings of the present study agree with Yadav et al. (1990) and Jat and Yadav (2010) observed that during the winter season a higher feed intake and body weight were observed in buffaloes calves in a conventional closed barn with open house rearing. However, Lowe et al. (2019) reported that using concrete slats or rubber covered slats did not affect bulls feed conversion efficiency.

\section{Conclusions}

Therefore, it is concluded that the conventional barn during night time and open paddock during day time ameliorate the cold stress and improved feed intake, feed conversion efficiency, water intake, body growth and average daily gain of Gir calves compared to other housing modified systems during the winter season in the semi-arid zone of Rajasthan. 


\section{Acknowledgments}

The authors are thankful to the Head, Department of Livestock Production Management, members of the advisory committee and Sri Karan Narendra Agriculture University authorities for providing research facilities and assistance during the experimental period.

\section{References}

Anderson N (2002) Observations on cow comfort using 24 hour time lapse video. $12^{\text {th }}$ international symposium on lameness in ruminants. Orlando, Florida. pp 27-34

AOAC (2000) Association of Official Analytical Chemists. Official Methods of Analysis. 17 $7^{\text {th }}$ Revised ed., AOAC: Washington, D.C.

Jat RP, Yadav BL, Gupta LR (2003) Intake and utilization of nutrients in buffalo calves as influenced by shelter managemental. 4th Asian buffalo congress, New Dehli. p186

Kailash, Jat RP, Bhinda R (2018) Physiological responses and economics of female cross-bred calves under different shelter managemental practices in semi- arid zone. Int J Curr Microbiol Appl Sci 7: 484489

Kailash, Jat RP, Choudhary BL, Yadav SP, Kumar S, Kumar V (2017) Effect of shelter managemental practices on growth and physiological responses of female cross-bred calves in semi-arid zone. Environ Ecol 35: 2300-2305
Kumar A, Kamboj ML, Chandra S, Bharti P (2018) Effect of modified housing system on physiological parameters of Murrah buffaloes during autumn and winter season. Indian J Anim Res 52: 829-833

Laxmi NA, Namagirilakshmi S, Dandage SD, Sehgal JP (2013) Relationship between plasma haptoglobin, monocyte toll like receptor 4 expression with growth and the effect of supplementation of fermented yeast culture on low body weight crossbred calves. Indian J Anim Res 47: 120-125

Lowe DE, Lively FO, Gordon AW (2019) The effect of diet and covering fully slatted concrete floors with rubber strips on the intake, performance and cleanliness of dairy-origin bulls. Animal 13: 20922100 .

McDowell RE (1972) Improvement of livestock production in warm climate. San Francisco (CA): WH Freeman and Co.

RP, Yadav BL (2010) Growth and behavioural pattern of buffalo calves under different shelter modifications during winter. Indian J Anim Sci 80: 686-689

Shekhawat LS, Chaudhary JL (2012) Effect of roof modifications in loose house on intake and utilization of nutrients and milk yield in lactating crossbred cows during winter season. J Dairy Sci 65: 501-507

Sinha R, Kamboj ML, Lathwal SS Ranjan A (2018) Effect of housing management on production performance of crossbred cows during hot-humid season. Indian J Anim Res 52: 1091-1094

Yadav RS, Yadav MS, Singh MP, Ram K (1990) Effect of provision of bedding and jacketing on growth performance of buffalo calves during winter season. Indian J Anim Prod Manage 6: 195-200 